\title{
Assessment on performance and variability in different sweet orange (Citrus sinensis Obseck) cultivars under Punjab conditions
}

\author{
Arvind Kumar Baswal*, H. S. Rattanpal, Gurteg Singh Uppal and K. S. Gill \\ Department of Fruit Science, Punjab Agricultural University, Ludhiana - 141004 (Punjab), INDIA \\ *Corresponding author. E-mail: baswal.arvind0@gmail.com \\ Received: August 10, 2016; Revised received: January 22, 2017; Accepted: April 17, 2017
}

\begin{abstract}
Based on morphological characterization, the performance of eighteen sweet orange, (Citrus sinensis Obseck) cultivars were evaluated. On the basis of two year data, the maximum mean fruit weight (316.25 gm) was recorded in Moro, while the maximum mean fruit diameter and mean fruit length was recorded in Mosambi and Olinda Valencia ( $87.32 \mathrm{~mm}$ and $81.33 \mathrm{~mm}$, respectively). Albedo thickness was recorded maximum in Ruby Nucellar $(3.42 \mathrm{~mm})$. Highest total soluble solids was recorded in cultivar Moro ( $11.45^{\circ}$ brix), while the titratable acidity was recorded maximum in Valencia Calizonida $(1.21 \%)$. Fruit axis diameter and Fruit rind thickness were recorded maximum in Rhode Red Valencia and Vernia $(15.12 \mathrm{~mm}$ and $8.11 \mathrm{~mm}$, respectively). In the variability studies, the maximum genotypic coefficient of variance (GCV) and phenotypic coefficient of variance (PCV) was recorded maximum for titratable acidity (27.88 and 27.94, respectively) followed by albedo thickness (23.77 and 23.78 , respectively) and fruit weight (21.52 and 21.67, respectively). Genetic advance per cent of mean was recorded for titratable acidity $(57.31 \%)$ followed by albedo thickness $(48.96 \%)$ and fruit weight $(44.03 \%)$ suggesting that further selection will be effective for improvement in these traits.
\end{abstract}

Keywords: Cultivars, Physico-chemical characters, Sweet orange, Variability

\section{INTRODUCTION}

Citrus is a sub-tropical fruit and belongs to family Rutaceae. It is one of the most famous fruits grown all over the world. The north-eastern region of India is considered as one of the natural home of few citrus species. The genus Citrus belongs to the tribe Citreaea, subtribe Citrinae subfamily Aurantioideae. Citrus is grown in every tropical country and in those regions of sub-tropical countries, where winter temperature do not fall below $0{ }^{\circ} \mathrm{C}$. Morphological study is an essential tool for the assessment of diversity and classification. Even today, morphological study is being considered and has been deployed as an initial step for cultivar identification and diversity assessment with watermelon (Huh et al., 2008), sweet potato (Elameen et al., 2010) and agave (Rodrguez et al., 2009). Furthermore, important horticultural characters are reported to be controlled by multiple genes (Campos et al., 2005, Liu and Deng 2007) and are of low heritability. A recent study on genetic resources of Citrus in northeastern India indicated the presence of 23 species, one sub-species and 68 varieties, thus this area acquired a special status as a treasure house of citrus germplasm (Sharma et al., 2004). Thus, morphological characterization could be an essential component since most of the horticultural characters cannot be evaluated through molecular markers. Keeping in view that availability of wide range of citrus cultivars at Punjab
Agricultural University, Ludhiana, the present study was planned to analyze the variability of sweet oranges cultivars for different morphological characters.

\section{MATERIALS AND METHODS}

The investigation was carried out during the years 2013 to 2015 on sweet orange (Citrus sinensis) grown and maintained in the College Orchard and Fruit Research Farm, Department of Fruit Science, Punjab Agricultural University, Ludhiana, Punjab. Characterization of sweet orange cultivars was conducted on eighteen genotypes on the basis of IPGRI (International Plant Genetic Resources Institute) citrus descriptors (Anonymous, 1999). Each cultivars was replicated four times with one plant per replication. For each fruit character, ten fruits/plant were collected randomly and observations were recorded on each fruit separately. Parameters like fruit diameter, fruit length, albedo thickness, fruit rind thickness, fruit axis diameter, were recorded using Digital Vernier Calipers. Total soluble solids content of fully mature fruits was recorded using Digital Hand Refractrometer. Titrable acidity was estimated by titrating a known volume of pulp juice extracted against $0.1 \mathrm{~N}$ Sodium hydroxide $(\mathrm{NaOH})$ using phenolphthalein as an indicator. Data were analyzed statistically to an analysis of variance (ANOVA) and differences among the means were determined for significance at $\mathrm{p}<0.05$ by LSD test using 
the statistical analysis system software version 9.3 (SAS Institute Inc., Cary, NC, USA) at $5 \%$ level of probability. Mean and standard errors of each sample were calculated for statistical comparison (Singh et al., 1998). The phenotypic and genotypic coefficients of variation were calculated as per formula described by Burton (1952) and Burton and de Vane (1953). Heritability, in broad sense, was calculated as suggested by Allard (1960) and genetic advance per cent of mean was calculated following the method suggested by Johnson et al. (1955).

\section{RESULTS AND DISCUSSION}

The results (Table 1 and 2 ) revealed that the maximum fruit weight (316.25 g) was recorded in cultivar Moro followed by Mosambi (288.25 g) and Rhode Red Valencia (276.25 gm), while the minimum mean fruit weight was recorded in Crescent Orange (135.75 g). The maximum mean fruit length $(81.33 \mathrm{~mm})$ was recorded in cultivar Olinda Valencia which was statistically at par with Mosambi, Tarocco, Campbell Valencia and Olinda Valencia, respectively, while, the minimum mean fruit length $(64.98 \mathrm{~mm})$ was recorded in cultivar Crescent Orange. The maximum mean fruit diameter $(87.32 \mathrm{~mm})$ was recorded in cultivar Mosambi which was statistically at par with Fukumoto Navel, Campbell Valencia, Rhode Red Valencia and Ruby Nucellar, respectively. The minimum mean fruit

Table 1. Physico-chemical analysis of eighteen sweet orange cultivars (2013-2015).

\begin{tabular}{|c|c|c|c|c|c|}
\hline Cultivars & $\begin{array}{c}\text { Density of oil } \\
\text { glands } / \mathrm{cm}^{2}\end{array}$ & $\begin{array}{c}\text { Fruit diameter } \\
(\mathrm{mm})\end{array}$ & $\begin{array}{c}\text { Fruit length } \\
(\mathrm{mm})\end{array}$ & $\begin{array}{c}\text { Fruit weight } \\
\text { (g) }\end{array}$ & $\begin{array}{c}\text { Albedo thickness } \\
\text { (mm) }\end{array}$ \\
\hline Campbell Valencia & $81.75^{\mathrm{jk}}$ & $78.83^{\text {cde }}$ & $77.70^{\text {cd }}$ & $252.75^{\mathrm{de}}$ & $2.45^{\mathrm{h}}$ \\
\hline Crescent Orange & $84.75^{\mathrm{ijk}}$ & $61.47^{\mathrm{j}}$ & $64.98^{j}$ & $135.75^{\mathrm{k}}$ & $1.74^{\mathrm{k}}$ \\
\hline Cutter Valencia & $93.00^{\mathrm{hij}}$ & $77.37^{\mathrm{ef}}$ & $65.53^{\mathrm{ij}}$ & $244.50^{\mathrm{e}}$ & $3.06^{\mathrm{c}}$ \\
\hline Early Gold & $168.25^{\mathrm{a}}$ & $85.95^{\mathrm{a}}$ & $77.16^{\mathrm{d}}$ & $205.00^{\text {ghi }}$ & $2.64^{f}$ \\
\hline Fukumoto Navel & $98.75^{\mathrm{gh}}$ & $79.36^{\mathrm{cd}}$ & $72.63^{f}$ & $228.02^{f}$ & $2.86^{\mathrm{d}}$ \\
\hline Itaborai & $120.5^{\text {bcd }}$ & $86.20^{\mathrm{a}}$ & $70.02^{\mathrm{gh}}$ & $212.50^{\mathrm{fgh}}$ & $3.15^{\mathrm{b}}$ \\
\hline Jaffa & $103.25^{\mathrm{fgh}}$ & $69.3^{\mathrm{h}}$ & $68.91^{\mathrm{h}}$ & $171.50^{\mathrm{j}}$ & $1.45^{\mathrm{m}}$ \\
\hline Moro & $100.00^{\text {fgh }}$ & $87.29^{\mathrm{a}}$ & $79.17^{\mathrm{bc}}$ & $316.25^{\mathrm{a}}$ & $3.13^{\mathrm{b}}$ \\
\hline Mosambi & $84.25^{\mathrm{ijk}}$ & $87.32^{\mathrm{a}}$ & $78.41^{\mathrm{cd}}$ & $288.25^{\mathrm{b}}$ & $2.27^{\mathrm{i}}$ \\
\hline Olinda Valencia & $132.00^{\mathrm{b}}$ & $76.35^{\mathrm{f}}$ & $81.33^{\mathrm{a}}$ & $246.00^{\mathrm{e}}$ & $2.76^{\mathrm{e}}$ \\
\hline Rhode Red Valencia & $78.50^{\mathrm{k}}$ & $78.11^{\mathrm{de}}$ & $80.92^{\mathrm{ab}}$ & $276.25^{\mathrm{bc}}$ & $1.57^{1}$ \\
\hline Ruby Nucellar & $107.25^{\mathrm{efg}}$ & $78.05^{\mathrm{de}}$ & $68.79^{\mathrm{h}}$ & $200.00^{\mathrm{hi}}$ & $3.42^{\mathrm{a}}$ \\
\hline Sanguinelli & $80.00^{\mathrm{k}}$ & $69.69^{\mathrm{h}}$ & $66.94^{\mathrm{i}}$ & $147.00^{\mathrm{k}}$ & $2.16^{\mathrm{j}}$ \\
\hline Tarocco & $118.50^{\text {cde }}$ & $79.89^{c}$ & $78.28^{\mathrm{cd}}$ & $267.50^{\mathrm{cd}}$ & $3.11^{\mathrm{b}}$ \\
\hline Trovita & $95.25^{\mathrm{hi}}$ & $74.31^{\mathrm{g}}$ & $74.71^{\mathrm{e}}$ & $247.63^{\mathrm{e}}$ & $2.56^{\mathrm{g}}$ \\
\hline Valencia Calizonida & $123.00^{\mathrm{bc}}$ & $67.25^{\mathrm{i}}$ & $70.84^{\mathrm{fg}}$ & $178.25^{\mathrm{j}}$ & $2.16^{\mathrm{j}}$ \\
\hline Vernia & $174.75^{\mathrm{a}}$ & $74.62^{\mathrm{g}}$ & $66.21^{\mathrm{ij}}$ & $195.75^{\mathrm{i}}$ & $1.76^{\mathrm{k}}$ \\
\hline Westin & $111.25^{\mathrm{def}}$ & $83.54^{\mathrm{b}}$ & $77.00^{\mathrm{d}}$ & $218.00^{f g}$ & $2.63^{f}$ \\
\hline Mean & 108.61 & 77.50 & 73.31 & 223.94 & 2.49 \\
\hline $\operatorname{LSD}(\mathrm{p} \leq 0.05)$ & 11.60 & 1.65 & 1.82 & 16.07 & 0.04 \\
\hline
\end{tabular}

Table 2. Physico-chemical analysis of eighteen sweet orange cultivars (2013-2015).

\begin{tabular}{|c|c|c|c|c|c|}
\hline Cultivars & $\begin{array}{c}\text { Titratable } \\
\text { acidity }(\%)\end{array}$ & $\begin{array}{c}\text { TSS } \\
\left({ }^{0} \text { Brix }\right)\end{array}$ & $\begin{array}{c}\text { Fruit axis diame- } \\
\text { ter }(\mathrm{mm})\end{array}$ & $\begin{array}{c}\text { Fruit rind thick- } \\
\text { ness (mm) }\end{array}$ & $\begin{array}{c}\text { Number of } \\
\text { segments per fruit }\end{array}$ \\
\hline Campbell Valencia & $1.00^{\mathrm{b}}$ & $8.60^{\mathrm{de}}$ & $11.88^{\mathrm{h}}$ & $4.66^{\mathrm{m}}$ & $12.00^{\mathrm{abc}}$ \\
\hline Crescent Orange & $0.49^{\mathrm{h}}$ & $7.97^{\mathrm{f}}$ & $9.49^{\mathrm{m}}$ & $5.35^{\mathrm{j}}$ & $13.00^{\mathrm{a}}$ \\
\hline Cutter Valencia & $0.87^{\mathrm{c}}$ & $8.05^{\mathrm{f}}$ & $11.84^{\mathrm{h}}$ & $6.91^{\mathrm{c}}$ & $13.00^{\mathrm{a}}$ \\
\hline Early Gold & $0.46^{\mathrm{h}}$ & $10.35^{b}$ & $12.69^{\mathrm{d}}$ & $5.27^{\mathrm{k}}$ & $12.00^{\mathrm{abc}}$ \\
\hline Fukumoto Navel & $0.71^{\mathrm{d}}$ & $8.82^{\mathrm{d}}$ & $13.17^{\mathrm{b}}$ & $5.66^{\mathrm{h}}$ & $12.5^{\mathrm{ab}}$ \\
\hline Itaborai & $0.62^{f}$ & $9.45^{\mathrm{c}}$ & $12.14^{\mathrm{g}}$ & $4.76^{1}$ & $12.50^{\mathrm{ab}}$ \\
\hline Jaffa & $0.73^{\mathrm{d}}$ & $8.55^{\mathrm{e}}$ & $12.81^{\mathrm{c}}$ & $4.12^{\circ}$ & $12.00^{\mathrm{abc}}$ \\
\hline Moro & $0.57^{\mathrm{g}}$ & $11.45^{\mathrm{a}}$ & $8.94^{\mathrm{n}}$ & $6.66^{\mathrm{e}}$ & $13.00^{\mathrm{a}}$ \\
\hline Mosambi & $0.65^{\mathrm{ef}}$ & $10.52^{b}$ & $10.47^{\mathrm{j}}$ & $3.84^{\mathrm{p}}$ & $12.25^{\mathrm{abc}}$ \\
\hline Olinda Valencia & $1.00^{\mathrm{b}}$ & $8.17^{\mathrm{f}}$ & $10.39^{\mathrm{k}}$ & $5.39^{j}$ & $13.00^{\mathrm{a}}$ \\
\hline Rhode Red Valencia & $0.57^{\mathrm{g}}$ & $8.15^{\mathrm{f}}$ & $15.11^{\mathrm{a}}$ & $6.97^{\mathrm{b}}$ & $12.75^{\mathrm{ab}}$ \\
\hline Ruby Nucellar & $0.64^{\mathrm{ef}}$ & $11.27^{\mathrm{a}}$ & $12.34^{\mathrm{f}}$ & $6.10^{\mathrm{g}}$ & $12.50^{\mathrm{ab}}$ \\
\hline Sanguinelli & $0.66^{\mathrm{e}}$ & $8.72^{\mathrm{de}}$ & $12.58^{\mathrm{e}}$ & $5.55^{\mathrm{i}}$ & $13.00^{\mathrm{a}}$ \\
\hline Tarocco & $0.66^{\mathrm{e}}$ & $8.48^{\mathrm{e}}$ & $6.86^{\circ}$ & $6.73^{d}$ & $11.25^{\mathrm{c}}$ \\
\hline Trovita & $0.63^{\mathrm{ef}}$ & $8.22^{\mathrm{f}}$ & $10.25^{1}$ & $6.17^{\mathrm{f}}$ & $12.50^{\mathrm{ab}}$ \\
\hline Valencia Calizonida & $1.21^{\mathrm{a}}$ & $8.20^{f}$ & $10.25^{1}$ & $4.37^{\mathrm{n}}$ & $12.25^{\mathrm{abc}}$ \\
\hline Vernia & $0.73^{d}$ & $8.22^{\mathrm{f}}$ & $11.63^{\mathrm{i}}$ & $8.11^{\mathrm{a}}$ & $11.75^{\mathrm{bc}}$ \\
\hline Westin & $0.54^{\mathrm{g}}$ & $10.52^{b}$ & $10.27^{1}$ & $6.09^{c}$ & $12.00^{\mathrm{abc}}$ \\
\hline Mean & 0.71 & 9.09 & 11.29 & 5.71 & 12.40 \\
\hline $\operatorname{LSD}(\mathrm{p} \leq 0.05)$ & 0.04 & 0.25 & 0.04 & 0.06 & 1.15 \\
\hline
\end{tabular}


Arvind Kumar Baswal et al. / J. Appl. \& Nat. Sci. 9(2): 780 - 783 (2017)

Table 3. Variability, heritability and genetic advance in sweet orange cultivars.

\begin{tabular}{|c|c|c|c|c|c|c|}
\hline Characters (Sweet oranges) & GV & $\mathbf{P V}$ & GCV & PCV & $h^{2}(\%)$ & GA (\% of mean) \\
\hline Density of oil glands $/ \mathrm{cm}^{2}$ & 757.67 & 774.42 & 25.34 & 25.62 & $98 \%$ & 51.64 \\
\hline Fruit diameter $(\mathrm{mm})$ & 52.45 & 52.79 & 9.35 & 9.38 & $99 \%$ & 19.19 \\
\hline Fruit length (mm) & 31.05 & 31.47 & 7.60 & 7.65 & $99 \%$ & 15.56 \\
\hline Fruit weight (g) & 2322.91 & 2355.01 & 21.52 & 21.67 & $99 \%$ & 44.03 \\
\hline Albedo thickness (mm) & 0.35 & 0.35 & 23.77 & 23.78 & $100 \%$ & 48.96 \\
\hline Acidity (\%) & 0.04 & 0.04 & 27.88 & 27.94 & $100 \%$ & 57.31 \\
\hline Total soluble soilds (TSS) & 0.24 & 0.25 & 5.68 & 5.85 & $94 \%$ & 11.37 \\
\hline Fruit axis diameter (mm) & 3.51 & 3.51 & 16.61 & 16.61 & $100 \%$ & 34.22 \\
\hline Fruit rind thickness (mm) & 1.26 & 1.26 & 19.72 & 19.72 & $100 \%$ & 40.62 \\
\hline Number of segments per fruit & 0.09 & 0.26 & 2.46 & 4.10 & $36 \%$ & 3.03 \\
\hline
\end{tabular}

Where, $\mathrm{GV}=$ genotypic variance, $\mathrm{PV}=$ phenotypic variance, $\mathrm{GCV}=$ genotypic coefficient of variance, $\mathrm{PCV}=$ phenotypic coefficient of variance, $\mathrm{h}^{2}=$ heritability in broad sense and GA = genetic advance

diameter $(61.47 \mathrm{~mm})$ was recorded in cultivar Crescent Orange. The results are supported with the findings of Roy et al (2014) who reported that Type-4 pummelo had the maximum fruit weight $(1.35 \mathrm{~kg})$ as compared to Type-7 pummelo $(0.78 \mathrm{~kg}$ per fruit). Likewise, albedo thickness was recorded maximum in the cultivar Ruby Nucellar $(3.42 \mathrm{~mm})$ followed by Itaborai $(3.15$ $\mathrm{mm})$ and Moro $(3.13 \mathrm{~mm})$, respectively, while the minimum mean albedo thickness was noted in cultivar Jaffa $(1.45 \mathrm{~mm})$. Similarly, Fruit axis diameter was recorded maximum in cultivars Rhode Red Valencia $(15.12 \mathrm{~mm})$ which was statistically at par with cultivar Westin, Valencia Calizonida and Trovita, while the lowest mean fruit axis diameter was found in cultivar Tarocco $(6.86 \mathrm{~mm})$. Fruit rind thickness was recorded as maximum in cultivar Vernia $(8.11 \mathrm{~mm})$ which was statistically at par with Olinda Valencia and Crescent Orange, while the minimum mean fruit rind thickness was found in Mosambi (3.84 mm). Physicochemical traits such as total soluble solids (TSS) was recorded maximum in cultivar Moro $\left(11.45^{\circ}\right.$ brix) which was statistically at par with cultivar Trovita, Vernia, Valencia Calizonida, Olinda, Rhode Red Valencia, Cutter Valencia and Crescent Orange, while the minimum mean total soluble solids was observed in Crescent Orange $\left(7.97^{\circ}\right.$ brix). Likewise, the maximum mean acidity percentage was recorded in Valencia Calizonida (1.21\%) which was statistically at par with cultivar Sanguinelli, Tarocco, Mosambi, Ruby Nucellar and Trovita, while the minimum mean titratable acidity percentage was observed in Early Gold (0.46 $\%)$. Number of segments per fruit was recorded maximum in cultivar Crescent Orange (13 segments per fruit) followed by Cutter Valencia (13 segments per fruit), while the minimum mean number of segments per fruit were recorded in cultivar Tarocco (11.25 segments per fruit).

These results also corroborate with the findings of Baswal et al. (2015) who reported that Foster grapefruit ( $C$. paradisi) had the maximum fruit length and fruit diameter (94.61 and 118.75, respectively) while, Marsh seedless had the minimum fruit length and fruit diameter (79.95 and $98.42 \mathrm{~cm}$, respectively). Physico- chemical traits such total soluble solids was recorded maximum from the fruits of Ruby Red ( $8.81^{\circ}$ brix), while the minimum total soluble solids was obtained from the fruits of Rio Red $\left(8.25^{\circ}\right.$ brix $)$

Similarly, Roy et al. (2014) who reported that Type-4 pummelo had the maximum fruit weight $(1.35 \mathrm{~kg})$ in contrast to Type-7 pummelo $(0.78 \mathrm{~kg})$.

In the variability studies, a wide range of variability was observed for all the fruit characters (Table 3 ). The co-efficient of variation (both genotypic and phenotypic) was higher for the characters like titratable acidity (27.88 and 27.94, respectively) followed by albedo thickness (23.77 and 23.78, respectively) and fruit weight (21.52 and 21.67, respectively). GCV associated with high heritability ( $80 \%$ or more) indicated that selection would be effective for the improvement of these characters but for a character with low heritability (40\% or less) selection may be comparatively difficult or virtually impractical due to masking effect of the environment on the genotypic effects. This indicated that selection for titrable acidity, albedo thickness and fruit weight would be effective. In the present investigation high genetic advance per cent of mean was the maximum for density of oil glands $/ \mathrm{cm}^{2}$ $(51.64 \%)$ followed by albedo thickness (48.96\%) and fruit weight $(44.03 \%$, respectively. So, selection would be highly effective for these traits. These variability results also follow the findings of Baswal et al (2015) who reported that maximum genetic advance per cent of mean was recorded for density of oil glands $(71.43 \%)$ followed by albedo thickness (40.07\%).

\section{Conclusion}

Among the eighteen cultivars of sweet orange studied Moro, Mosambi and Rhode Red Valencia and Trovita had the maximum fruit weight $(316.25,288.25,276.25$ and $247.63 \mathrm{~g}$, respectively), fruit length $(79.17,78.41$, 80.92 and $74.71 \mathrm{~cm}$, respectively) and total soluble solids $\left(11.45,10.52,8.15\right.$ and $8.22^{\circ}$ brix, respectively. These cultivars of sweet orange may be suitable for its commercial cultivation. 


\section{ACKNOWLEDGEMENTS}

The authors are grateful to Dr. Karanbir Singh gill, Assistant Professor, Department of Fruit Science, Punjab Agricultural University, Ludhiana for his immense help in data analysis.

\section{REFERENCES}

Allard, R. W. (1960). Principles of Plant Breeding. John Wiley and Sons Inc., New York, United States of America, Pp. 83-108

Anonymous. (1999). Descriptors for citrus. International Plant Genetic Resources Institute, Rome, Italy. Pp. 3436

Baswal, A.K., Rattanpal, H.S. and Sidhu, G.S. (2015). Varietal assessment and variability studies in grapefruit (Citrus paradisi Mac Fadyen) genotypes in subtropical zones of Punjab, India

Burton, G.W. (1952). Quantitative inheritance in grasses. Proc VI Int Grassland Cong., Pp. 277-83

Burton, G. W. and deVane, E. W. (1953). Estimating heritability in tall fescue (Festuca arundinacea) from replicated clone material. Agron J, 45: 475-81

Campos, E.T., Espinosa, M.A.G., Warburton, M.L., Varela A. M. and Monter, A. V. (2005). Characterization of mandarin (Citrus spp.) using morphological and AFLP markers. Formato Documento Electronico (ISO) 30:687-93

Elameen, A., Larsen, A., Sonja, S. K., Fjellheium, S., Msol- la, S., Masumba, E. and Rognli, O. A. (2010). Phenotypic diversity of plant morphological and root descriptor characters within a sweet potato, Ipomoea batatas (L.) germplasm collection from Tanzania. Genet Resour Crop Evol., 58: 397-407

Huh, Y. C., Solmaz, I. and Sari, N. (2008). Morphological characterization of Korean and Turkish watermelon germplasm. Proc IXth EUCARPIA International Meeting on Cucurbitaceae.

Johnson, H. W., Robinson, H. F. and Comstock, R. E. (1955). Estimates of genetics and environmental variability in soyabean. Agron J, 47: 314-18

Liu, Y. Z. and Deng, X. X. (2007). Citrus breeding and genetics in China. Asian Australas J Plant Sci Biotech., 1: 23-28. (ISO) 30: 687-93

Rodrguez, G. B. , Lomel, S. J. A., Tapia, C. E. A., Gutiarrez, M., Garc- a-Galind, J., Rodrguez, D. J., Urbina, L. D. and Vicente, R. I. (2009). Morphological and molecular diversity of Agave tequilana Weber var. Azul and Agave angustifolia Haw. var. Lineo. Ind Crops Prod., 29: $220-28$

Roy, D., Kundu, S., Ghosh, B., Dutta, P. and Pal, R. (2014). Performance of pummelo germplasm in new alluvial zone of west bengal. J Crop and Weed, 10: 179-82

Sharma, B. D., Hore, D. K. and Gupta, S. G. (2004). Genetic resources of Citrus of north-eastern India and their potential use. Genet Resour Crop Evol., 51: 411-18

Singh, S., Bansal, M. L., Singh, T. P. and Kumar R. (1998). Statistical Method for Research Workers. Pp. 310-17. Kalyani Publishers, New Delhi, India. 